\title{
SURFACE CARBON STOCKS OF SOIL UNDER PISTACHIO COVER ON SOUTHEASTERN TURKEY
}

\author{
ÇELIK, A. ${ }^{1 *}-$ SAKIN, E. D. ${ }^{2}-$ SAKIN, E. $^{3}-$ SEYREK, A. ${ }^{3}$ \\ ${ }^{1}$ University of Adiyaman, Vocational Schools in Kahta, Plant and Animal Production \\ Department, 02400, Adiyaman, Turkey.E-mail: ahmetcelik@adiyaman.edu.tr \\ (phone: +904167258150; fax: +904167257792) \\ ${ }^{2}$ Republic of Turkey Ministry of Food, Agriculture and Livestock of Directorate GAP \\ Agricultural Research Institute Sanliurfa, Turkey \\ ${ }^{3}$ Department of Soil Science and Plant Nutrient of Agriculture, Faculty of Harran University, \\ Sanliurfa, Turkey \\ *Corresponding author \\ e-mail:ahmetcelik@adiyaman.edu.tr \\ (Received 10 $0^{\text {th }}$ Dec 2016; accepted $2^{\text {nd }}$ Mar 2017)
}

\begin{abstract}
Soil plays an important role in global carbon cycle in arid and semi-arid regions. Carbon stocks (CS) are the most significant and widespread of terrestrial carbon components. As in the past, soil carbon has still been considered as a soil quality parameter. Knowledge of the soil carbon stock is quite important for global carbon cycle. Small changes that occur in surface soil where most of the carbon stock is contained affect atmospheric carbon dioxide $\left(\mathrm{CO}_{2}\right)$. Soil samples were taken from the pistachio covered soils at $0-20 \mathrm{~cm}$ depth, and were analyzed. As result of the study, it was determined that soil samples contained $0.07-1.95 \%$ soil organic carbon (SOC), and $12.7-42.81 \%$ calcareous. Whereas SOC concentration of the soils was $0.19-4.44 \mathrm{~kg} \mathrm{C} \mathrm{m}^{-2}$, soil inorganic carbon (SIC) concentrations were determined to be $1.53-14.08 \mathrm{~kg} \mathrm{C} \mathrm{m}^{-2}$. SOC and SIC stocks of the study area soils were identified as 0.17$0.39 \mathrm{Tg}$ and $0.033-1.25 \mathrm{Tg}\left(1 \mathrm{Tg}=10^{12} \mathrm{~g}\right)$, respectively. It was found that SOC content of the soils in arid and semi-arid regions was lower than moist climate regions. Insufficient precipitation, low biomass and low level of carbon input into the soil have all caused carbon content to be low. However, it was considered that the clay and calcareous content of the soil, especially the high clay content, protected SOC against weathering and decomposition. The correlation between soil parameters, a very significant and positive correlation was determined between SOC and soil clay content $\left(r^{2}=0.246, p<0.01\right)$.
\end{abstract}

Keywords: soil quality, carbon stock, pistachio soil, soil surface, organic carbon

\section{Introduction}

Soils are the greatest reserve of terrestrial carbon stocks, and the amount in soil is three times that of vegetation and two times that of the atmosphere. The soils have been reported to have $1500 \mathrm{Pg} \mathrm{C}$ (Schlesinger and Andrews, 2000) and $1580 \mathrm{Pg} \mathrm{C}$ (Houghton, 2007) at $1 \mathrm{~m}$ depth, and $2500 \mathrm{Pg} \mathrm{C}$ (Amundson, 2001) at $2 \mathrm{~m}$ depth. Carbon content of vegetation was reported to be $650 \mathrm{Pg} \mathrm{C}$ by Batjes and Sombroek (1997), $610 \mathrm{Pg} \mathrm{C}$ by Houghton (2007) and atmospheric carbon content was reported to be $750 \mathrm{Pg} \mathrm{C}$ by Batjes and Sombroek(1997) and $800 \mathrm{Pg} \mathrm{C}$ by Houghton (2007). In a study carried out by Janzen (2004), it was reported that the carbon content found under the soil at $1 \mathrm{~m}$ depth was mostly in an inorganic form. It is obvious that significant amount of the ground surface carbon is found in forest cover and ecosystems.

Soils are the largest and most significant pools of soil organic carbon (SOC) in terrestrial ecosystems. Even the smallest change in soil organic carbon pools affects 
atmospheric carbon dioxide $\left(\mathrm{CO}_{2}\right)$ (Xu et al., 2011). To determine soil organic carbon stocks (SOCs), it is necessary to know the significance of the role of the soil in global carbon cycle (Yong et al., 2007). There is not much information on carbon stocks in Turkey soils apart from a few studies (Sakin, 2010; Sakin, 2013; Sakin et al., 2015). And there are no studies carried out on soil surface carbon stocks except from the ones carried out in local areas (Sakin et al., 2014; Arul Pragasan, 2016).

Determination of soil organic carbon in regional, national and global scales is important for understanding the changes in carbon emissions (Batjes and Dijkshoorn, 1999; Yimer et al., 2006). It is necessary to determine carbon stocks in different soil types (Novaes Filho et al., 2007) and different soil depths in order to understand the risks of global carbon stocks upon global climate change (Egbe and Tabot, 2011). A significant part of soil organic carbon and stocks are on the soil surface. Carbon dioxide emissions due to changes that occur or will occur on soil surface creates a great risk (Yimer et al., 2006). Losses of nature areas and soil ecosystems have a remarkable economic impact (Martinez et al., 2009; Oladele and Braimoh, 2014). Thus, it is necessary to have knowledge on SOC dynamics in the ecosystems in different areas of the world (Garcia-Pausas et al., 2007) and in different depths of soil.

In their study upon surface carbon stocks of the soil $(0-5 \mathrm{~cm})$ under different cultivation conditions (forests, cleared areas, pastureland and forested areas), Schwendenmann et al. (2007) found concentration of surface carbon stocks as 2.24, $1.56,1.59$, and $2.94 \mathrm{~kg} \mathrm{C} \mathrm{m}^{-2}$, respectively. In their study upon the surface soil (0-20 $\mathrm{cm}$ ) carbon stocks of the region, Sakin et al. $(2014 ; 2015)$ determined concentration of SOC amounts between 1.6-4.36 $\mathrm{kg} \mathrm{C} \mathrm{m}^{-2}$, SIC amounts between 0.00-6.00 $\mathrm{kg} \mathrm{C} \mathrm{m}^{-2}$, and SOC and SIC stocks between 24.43-65.57 and 0.00-91.62 Tg, respectively.

Pistachio (Pistacia vera L.) is a fruit that is member of Anarcardiaceae genus. Besides being an important with its fruit, it has also been significant for medical uses in terms of the essential oil and resin it has. Although the plant has 11 species (Zohary, 1952), Pistacia vera L. is the only species that has production due to its economic return (Ak et al., 1998). Pistacia species as the wild pistachio has had a wide distribution in Turkey. Turpentine trees Pistacia terebinthus L. are the most common one among the wild species (Bilgen, 1973). This could grow in areas that do not require much soil, that are poor in terms of nutrients and the areas with rocky and calcareous soil. Especially in regions where the precipitation is insufficient $(300-500 \mathrm{~mm})$, pistachio cultivation is extremely economic.

The purpose of this study, as being different from the abovementioned studies, was to determine surface carbon stock amounts of the soils $(0-20 \mathrm{~cm})$ where pistachio cultivation is predominant in Turkey (282.334 ha) and in southeastern Turkey (88.507 ha).

\section{Materials and Methods}

\section{Study area}

The study area was located between Birecik (37 00" 09' N - 38 43" 31' E) and Halfeti $\left(37^{\circ} 14^{\prime \prime} 31^{\prime} \mathrm{N}-38^{\circ} 00^{\prime \prime} 33^{\prime} \mathrm{E}\right)$ districts on the west of Sanliurfa province in southeastern Turkey. Birecik and Halfeti districts have an altitude varying between 344 and $360 \mathrm{~m}$ (Figure 1). Although the region has a continental climate, it was also affected by the Mediterranean climate. Winters are warm, and summers are very hot. The average annual highest temperature has been measured in July $\left(40.2^{\circ} \mathrm{C}\right)$ and the 
average annual lowest temperature was measured in January $\left(1.3^{\circ} \mathrm{C}\right)$. Annual average precipitation is $342.5 \mathrm{~mm}$, and this value is quite low for agricultural production.

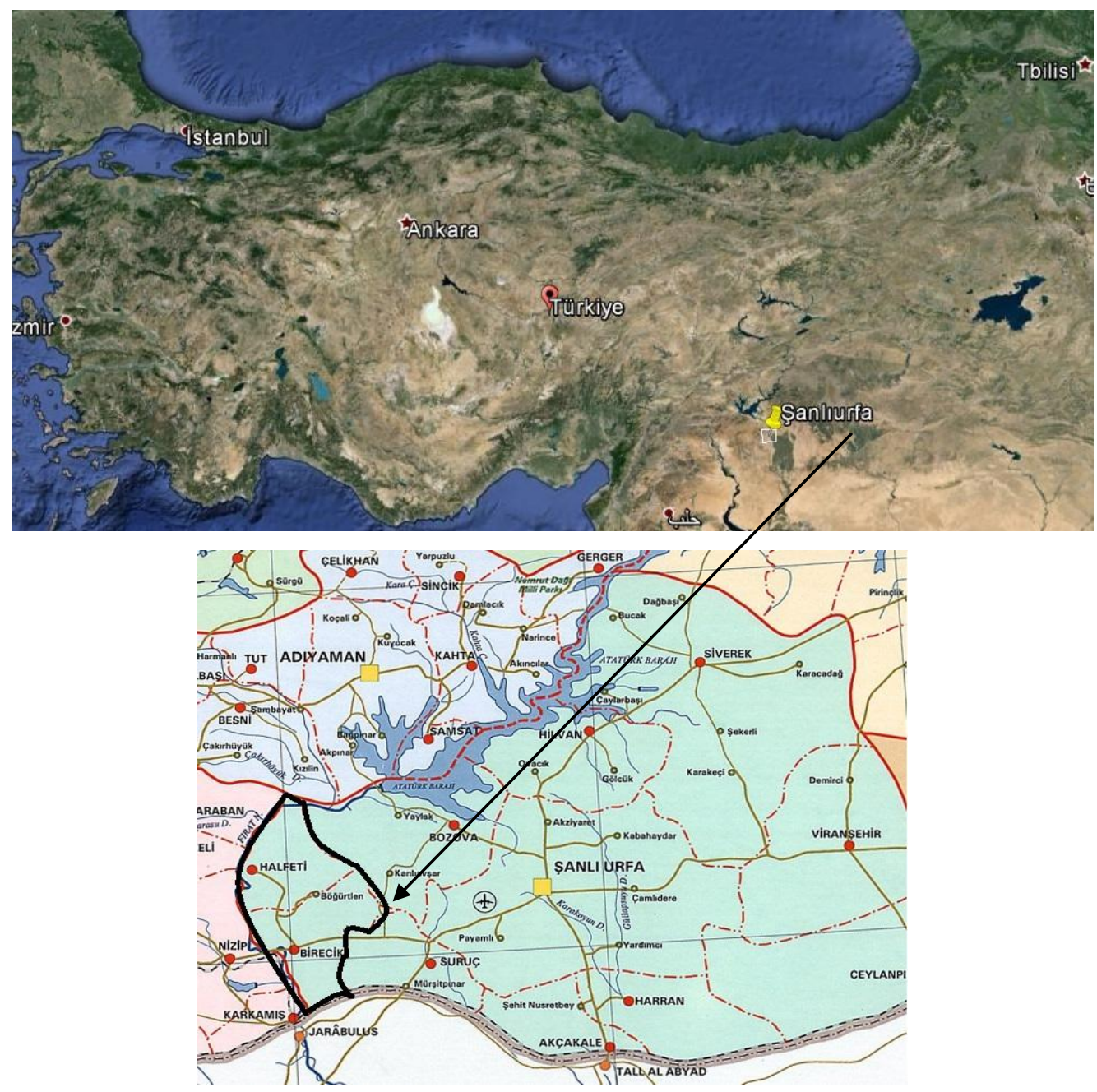

Figure 1. Location of study area

The soil property in the study area was included in brown and reddish brown soil groups. The soils had ABC profile, and contained high amounts of calcium. Therefore, calcification played an important role in soil formation (KHGM, 1961). Soils were classified as neutral and low alkali (US. Salinity Lab. Staff, 1954). Soil organic carbon content of the soils was low, and the soils had no salinity problem (Sakin, 2010). In general, pistachio vegetation was predominant, and the areas between the trees were covered with weed.

\section{Methods}

The soil samples were collected randomly at 0-20 cm depth from the study area. Collected soil samples were air dried, and subsequently, sieved through a $<2 \mathrm{~mm}$ sieve. Soil sample bulk densities (BD) were calculated using the equation established by Sakin et al. (2011) (Eq. 1). Soil surface organic carbon concentrations were calculated using Equation 2 mentioned below, and Equation 3 was used to calculate carbon stocks. 
Here in the equations, BD, bulk density $\left(\mathrm{g} \mathrm{cm}^{-3}\right)$; SOM, soil organic matter (\%); $\mathrm{SOCd}$, soil organic carbon concentration density $\left(\mathrm{kg} \mathrm{m}^{-2}\right)$; $\mathrm{SOC}$, soil organic carbon (\%); Di, depth (cm); SOCs, soil organic carbon stocks $(\mathrm{Tg}) ; \mathrm{A}$, area $\left(\mathrm{m}^{2}\right)$.

The other analyses were carried out according to texture (Bouyoucus, 1951), cation exchange capacity (Jackson, 1958), soil reaction (Janzen, 1993), electrical conductivity (Janzen, 1993), and organic matter (Walkley, 1947) methods.

\section{Results}

Descriptive statistics values related to soil parameters were presented in Table 1 . According to these data, SOC content values of the soils were between minimum $0.07 \%$ and maximum $1.95 \%$, and the minimum value for the soils of the area was determined to be quite low, and the maximum value was high (Jackson, 1958). The soil samples with low organic carbon content were generally found to be on the southern, rocky and calcareous area. The samples with high organic carbon content were generally determined on the north with high precipitation, much biomass and clay soil. Among the region soil, areas with high SOC content were limited. Such areas were usually observed in uncultivated areas and in the northern regions where the precipitation rate was relatively high. Low SOC content in the soils was considered to be the result of arid and semi-arid nature of the region, low soil carbon input, high decomposition and disintegration, removal or burning of the stubble waste or their use as a fuel (Sakin, 2010). For instance, it was determined that whereas the surface SOC amount of the soils in Sirnak was between 0.7-1.36\% (Sakin et al., 2016), the amount was between 0.73$1.69 \%$ in Cizre soils (Munis and Sakin, 2013).

Table 1. Descriptive of statistics of soil parameters

\begin{tabular}{lccccc}
\hline \multicolumn{1}{c}{ Soil Parameters } & Minimum & Maximum & Mean & Std. Error & Std. Deviation \\
\hline Sand $(\%)$ & 7.20 & 42.70 & 25.72 & 0.76 & 7.63 \\
Clay $(\%)$ & 23.00 & 50.00 & 31.81 & 0.71 & 7.05 \\
Silt $(\%)$ & 29.00 & 54.00 & 42.43 & 0.65 & 6.48 \\
CEC $\left(\mathrm{cmol} \mathrm{kg}^{-1}\right)$ & 20.00 & 40.00 & 41.71 & 1.46 & 14.69 \\
pH $(1: 2.5))$ & 6.95 & 7.67 & 7.30 & 0.013 & 0.13 \\
EC $\left(\mu \mathrm{S} \mathrm{cm}{ }^{-1}\right)(1: 5)$ & 0.30 & 0.82 & 0.48 & 0.010 & 0.106 \\
Calcareous $(\%)$ & 12.7 & 42.81 & 30.15 & 1.27 & 12.75 \\
Organic Carbon $(\%)$ & 0.07 & 1.95 & 0.84 & 0.0495 & 0.4950 \\
Bulk Density $\left(\mathrm{Mg} \mathrm{m}^{-3}\right)$ & 1.15 & 1.40 & 1.29 & 0.0067 & 0.0678 \\
\hline
\end{tabular}




\begin{tabular}{lccccc}
\hline SOC Concentration $\left(\mathrm{kg} \mathrm{C} \mathrm{m}^{-2}\right)$ & 0.19 & 4.44 & 2.09 & 0.11 & 1.14 \\
SIC Concentration (kg C m & -2 \\
SOC Stocks (Tg, Urfa) & 1.53 & 14.08 & 9.28 & 0.39 & 3.92 \\
SOC Stocks (Tg, Turkey) & 0.17 & 0.39 & 0.28 & 0.0102 & 0.1015 \\
SIC Stocks (Tg, Urfa) & 0.55 & 1.26 & 0.59 & 0.032 & 0.323 \\
SIC Stocks (Tg, Turkey) & 0.033 & 1.25 & 0.83 & 0.035 & 0.347 \\
\end{tabular}

Soil EC values were between 0.30 and $0.82 \mu \mathrm{S} \mathrm{cm}^{-1}$, and study area soil had no salinity problem (Anonymous, 1982). Lack of salt accumulation in the soil was remarkable for healthy plant growth, crop quality and quantity (Mengel and Kirkby, 1978). Soil reaction was slightly acidic, neutral and slightly alkali (US Salinity Lab. Staff, 1954). Since the region was arid and semi-arid, these $\mathrm{pH}$ values were considered as normal for the soil of the region.

Only a few studies have been carried out on soil surface carbon stocks of Turkey's Southeastern Anatolia Region (Sakin et al., 2014; Sakin et al., 2015; Sakin, 2016). Thus, comparisons in the present study were conducted with the results of international studies. In the study area, SOC concentrations varied between $0.19-4.44 \mathrm{~kg} \mathrm{C} \mathrm{m}^{-2}$. Soil organic carbon concentrations were found to be low in southern areas, and high in the northern areas. In a similar study carried out by Sakin et al. (2016) in Sirnak area, SOC concentrations of the soils were calculated as $1.22-2.79 \mathrm{~kg} \mathrm{~m}^{-2}$ whereas SIC concentrations were $1.08-40.36 \mathrm{~kg} \mathrm{~m}^{-2}$. The same authors also reported that soil SOC contents were similar to those in arid and semi-arid regions' soil SOC content, and SOC content was higher in uncultivated areas. It was determined that SOC content of the samples obtained from uncultivated lands was $1.37 \%$ as the highest, while the same value for cultivated lands was calculated as $0.4 \%$. The region was generally not expected to have high carbon content since the land was arid and semi-arid. In addition to high levels of dissolution and disintegration, there was low level of organic carbon and organic waste input into the soil. There was low level of accumulation due to this dissolution and disintegration. Because of this characteristic of the climate (aridity), the soil had low carbon deposit capacity. Sakin (2013) also obtained similar results in the studies carried out in the region. Furthermore, the researcher reported that soil SIC content was almost twice the soil SOC content in similar regions. Milne et al. (2007) stated that soil carbon accumulation rate was not constant and changed based on the topography, vegetation, climate, and the soil moisture content.

SIC concentrations in the soils collected from the study area were determined to be between 1.53 and $14.08 \mathrm{~kg} \mathrm{C} \mathrm{m}^{-2}$. Calcerous nature of the pistachio sampling areas caused high SIC concentrations in these samples. Munis and Sakin (2013) determined SIC concentrations to be $0.08-7.12 \mathrm{~kg} \mathrm{~m}^{-2}$ in the study they conducted in Cizre region, Sakin et al. determined SIC concentrations to be $1.08-40.36 \mathrm{~kg} \mathrm{~m}^{-2}$ in the study they conducted in Sirnak district's surface soil carbon stocks; Sakin et al. determined surface SIC concentrations to be $0.0-6.00 \mathrm{~kg} \mathrm{C} \mathrm{m}^{-2}$ in the study they carried out in Diyarbakir district, Sakin et al. determined SIC concentrations to be $1.97-11.85 \mathrm{~kg} \mathrm{C} \mathrm{m}^{-2}$ in the study they conducted in Mardin district, and Sakin et al. determined surface SIC concentrations to be $0.32-26.4 \mathrm{~kg} \mathrm{C} \mathrm{m}^{-2}$ in the study they conducted in Adiyaman district. In their study upon determining the surface carbon stocks of the soil $(0-5 \mathrm{~cm})$ 
under different cultivation conditions (forests, cleared areas, pastureland and forested areas), Schwendenmann et al. (2007) found surface carbon stocks were 2.24, 1.56, 1.59 and $2.94 \mathrm{~kg} \mathrm{C} \mathrm{m}^{-2}$, respectively. When the findings of this study were compared with the results of the previous studies carried out in the region, it was observed that the findings were similar with minute differences. And these small differences were arisen from the soil characteristics. In other words, it was revealed that these differences were normal when the soil was assessed in large soil groups. Since there was no lime in the formation of the soil formed on basaltic main material, these soils had no lime content, in general.

SOC and SIC stocks of the surface soils in the study area varied between 0.17 and $0.39(0.28) \mathrm{Tg}$, and 0.033 and $1.25(0.83) \mathrm{Tg}$, respectively. Approximately 2.29 fold difference was determined between maximum and minimum values of surface soil SOC stocks. This was considered to be arisen from the factors such as existence of different topographies, differences in climatic conditions in some areas, vectors (north-south), and cultivation procedures. Carbon stock deposits were not expected to be accumulated much in the region since the climate had arid and semi-arid climate. In addition to high dissociation and disintegration level, there was low organic carbon and organic waste input to the soil, and these factors were considered to be the reasons behind low carbon stock values. Accumulation level was low due to this dissociation and disintegration. Because of these climatic characteristics, the soil had low stock carbon capacity (Sakin et al., 2016). Sakin (2013) obtained similar results in the study carried out in the region. Furthermore, the researcher also reported that SIC stocks in the region were approximately two fold of SOC stocks.

\section{Discussion}

In a study carried out for determining surface soil carbon stocks of Adiyaman region, it was determined that soil SOC stock was $12.69 \mathrm{Tg}$, SIC stock was $57.23 \mathrm{Tg}$, and it was stated that soil SIC stock was 4.5 times more of SOC stock. It was assumed that soil SIC stocks and SIC/SOC ratio were high due to high soil lime content and low organic carbon content (Sakin, 2016). In another research carried out in Mardin district, that soil SOC stocks of the soils in the area were determined to be between 11.31 and $44.51 \mathrm{Tg}$ and SIC stocks were determined to be between 16.99-102.21 Tg, and soil SIC/SOC ratio was 2.54. These results were similar to the results of the international studies (Bouwman, 1990; Paul et al., 1997; Lal, 1995) that stressed significant effects of the land use systems on SOC pools, and also proved the lack of understanding on the effect of SIC pool on greenhouse gases. The researchers stated that SIC pools were especially observed in arid region soils, and SOC stocks were 2 to 5 times higher in these soils. Similar results were determined to be obtained when the findings of the studies in the literature and the findings of our study were compared.

The correlation values between soil analysis parameters of the soils in the study area were presented in Table 2. According to this, there was a very significant correlation between study area soil \% SOC content and soil \% clay content $\left(r^{2}=0.246, p<0.01\right)$, there was an insignificant positive correlation between soil \% SOC content and $\mathrm{pH}\left(\mathrm{r}^{2}=\right.$ $0.083, \mathrm{p}>0.05)$, EC $\left(\mathrm{r}^{2}=0.158, \mathrm{p}>0.05\right)$ and lime $\left(\mathrm{r}^{2}=0.163, \mathrm{p}>0.05\right)$, and very significant negative correlation with $\mathrm{BD}\left(\mathrm{r}^{2}=-0.999, \mathrm{p}<0.01\right)$. The negative relationship between soil SOC content and BD was a well-known correlation, and this was determined by several researchers (Sakin, 2016; Israelsen and Hansen, 1962). 
Table 2. Correlation of soil parameters

\begin{tabular}{|c|c|c|c|c|c|c|c|c|c|c|c|c|c|c|c|}
\hline \multicolumn{2}{|l|}{ Soil parameters } & \multirow{2}{*}{$\begin{array}{c}\text { Sand }(\%) \\
-0,617 * *\end{array}$} & \multirow[t]{2}{*}{ Silt (\%) } & \multirow[t]{2}{*}{$\begin{array}{l}\text { Clay } \\
(\%)\end{array}$} & \multirow[t]{2}{*}{$\begin{array}{c}\text { CEC } \\
\left(\mathrm{cmol} \mathrm{kg}^{-1}\right)\end{array}$} & \multirow[t]{2}{*}{ pH (1:2.5) } & \multirow[t]{2}{*}{$\begin{array}{c}\mathrm{EC} \\
(\mu \mathrm{S} \mathbf{c m})\end{array}$} & \multirow[t]{2}{*}{$\operatorname{SOM}(\%)$} & \multirow[t]{2}{*}{$\begin{array}{c}\text { Calcareous } \\
(\%)\end{array}$} & \multirow[t]{2}{*}{$\begin{array}{l}\text { SOC } \\
(\%)\end{array}$} & \multirow[t]{2}{*}{$\begin{array}{c}\text { BD } \\
\left(\mathrm{Mg} \mathrm{m}^{-3}\right)\end{array}$} & \multirow[t]{2}{*}{$\begin{array}{c}\text { SOC } \\
\left(\mathrm{kg} \mathrm{m}^{-2}\right)\end{array}$} & $\begin{array}{c}\text { SIC } \\
\left(\mathrm{kg} \mathrm{m}^{-2}\right)\end{array}$ & $\begin{array}{c}\text { SOC (Tg) } \\
\text { (Urfa) }\end{array}$ & $\begin{array}{r}\text { SOC }(\mathrm{Tg}) \\
\text { (Turkey) }\end{array}$ \\
\hline \multirow[t]{2}{*}{ Silt (\%) } & Pearson Correlation & & & & & & & & & & & & & & \\
\hline & Sig. (2-tailed) & 0,000 & & & & & & & & & & & & & \\
\hline \multirow[t]{2}{*}{ Clay (\%) } & Pearson Correlation & $-0,520 * *$ & $-0,370 * *$ & & & & & & & & & & & & \\
\hline & Sig. (2-tailed) & 0,000 & 0,000 & & & & & & & & & & & & \\
\hline \multirow{2}{*}{$\begin{array}{l}\text { CEC } \\
\left(\mathrm{cmol} \mathrm{kg}^{-1}\right)\end{array}$} & Pearson Correlation & $-0,250^{*}$ & $0,478 * *$ & $-0,224 *$ & & & & & & & & & & & \\
\hline & Sig. (2-tailed) & 0,012 & 0,000 & 0,026 & & & & & & & & & & & \\
\hline \multirow[t]{2}{*}{ pH (1:2.5) } & Pearson Correlation & $-0,117$ & $-0,128$ & $0,280 * *$ & $-0,094$ & & & & & & & & & & \\
\hline & Sig. (2-tailed) & 0,247 & 0,208 & 0,005 & 0,351 & & & & & & & & & & \\
\hline \multirow[t]{2}{*}{ EC (1:5) } & Pearson Correlation & $-0,303 * *$ & $0,525^{* *}$ & $-0,205^{*}$ & $0,347 * *$ & $-0,362 * *$ & & & & & & & & & \\
\hline & Sig. (2-tailed) & 0,002 & 0,000 & 0,042 & 0,000 & 0,000 & & & & & & & & & \\
\hline \multirow[t]{2}{*}{$\operatorname{SOM}(\%)$} & Pearson Correlation & $-0,115$ & $-0,099$ & $0,246^{*}$ & $-0,022$ & 0,038 & 0,158 & & & & & & & & \\
\hline & Sig. (2-tailed) & 0,254 & 0,331 & 0,014 & 0,828 & 0,705 & 0,116 & & & & & & & & \\
\hline \multirow[t]{2}{*}{ Calcareous (\%) } & Pearson Correlation & 0,078 & $-0,548 * *$ & $0,498 * *$ & $-0,573 * *$ & $0,326^{* *}$ & $-0,498 * *$ & 0,163 & & & & & & & \\
\hline & Sig. (2-tailed) & 0,438 & 0,000 & 0,000 & 0,000 & 0,001 & 0,000 & 0,106 & & & & & & & \\
\hline \multirow[t]{2}{*}{$\operatorname{SOC}(\%)$} & Pearson Correlation & $-0,115$ & $-0,099$ & $0,246 * *$ & $-0,022$ & 0,038 & 0,158 & $1,000 * *$ & 0,163 & & & & & & \\
\hline & Sig. (2-tailed) & 0,254 & 0,331 & 0,014 & 0,828 & 0,707 & 0,116 & 0,000 & 0,106 & & & & & & \\
\hline \multirow[t]{2}{*}{ BD $\left(\mathbf{M g ~ m}^{-3}\right)$} & Pearson Correlation & 0,115 & 0,103 & $-0,249^{*}$ & 0,029 & $-0,054$ & $-0,141$ & $-0,999 * *$ & $-0,168$ & $-0,999 * *$ & & & & & \\
\hline & Sig. (2-tailed) & 0,255 & 0,312 & 0,013 & 0,772 & 0,591 & 0,163 & 0,000 & 0,095 & 0,000 & & & & & \\
\hline \multirow[t]{2}{*}{$\operatorname{SOC}\left(\mathrm{kg} \mathrm{m}^{-2}\right)$} & Pearson Correlation & $-0,115$ & $-0,103$ & $0,250^{*}$ & $-0,031$ & 0,057 & 0,137 & $0,998 * *$ & 0,169 & $0,998 * *$ & $-1,000 * *$ & & & & \\
\hline & Sig. (2-tailed) & 0,255 & 0,309 & 0,013 & 0,760 & 0,571 & 0,174 & 0,000 & 0,093 & 0,000 & 0,000 & & & & \\
\hline \multirow[t]{2}{*}{$\operatorname{SIC}\left(\mathbf{k g ~ m}^{-2}\right)$} & Pearson Correlation & $0,092 * *$ & $-0,537 * *$ & $0,471^{* *}$ & $-0,582^{* *}$ & $0,320 * *$ & $-0,529 * *$ & 0,043 & $0,991 * *$ & 0,043 & $-0,049$ & 0,050 & & & \\
\hline & Sig. (2-tailed) & 0,361 & 0,000 & 0,000 & 0,000 & 0,001 & 0,000 & 0,672 & 0,000 & 0,672 & 0,629 & 0,620 & & & \\
\hline
\end{tabular}




$$
-754 \text { - }
$$

\begin{tabular}{|c|c|c|c|c|c|c|c|c|c|c|c|c|c|c|c|}
\hline SOC stock (Tg) & Pearson Correlation & $-0,115$ & $-0,103$ & $0,250^{* * *}$ & $-0,031$ & 0,056 & 0,137 & $0,998^{* *}$ & 0,169 & $0,998^{* *}$ & $-1,000^{* *}$ & $1,000^{* *}$ & 0,051 & & \\
\hline (Urfa) & Sig. (2-tailed) & 0,255 & 0,308 & 0,013 & 0,758 & 0,581 & 0,174 & 0,000 & 0,092 & 0,000 & 0,000 & 0,000 & 0,617 & & \\
\hline SOC stock (Tg) & Pearson Correlation & $-0,115$ & $-0,103$ & $0,250^{* * *}$ & $-0,031$ & 0,057 & 0,137 & $0,998^{* *}$ & 0,169 & $0,998^{* *}$ & $-1,000 * *$ & $1,000^{* *}$ & 0,050 & $1,000^{* *}$ & \\
\hline (Turkey) & Sig. (2-tailed) & 0,255 & 0,309 & 0,013 & 0,760 & 0,573 & 0,174 & 0,000 & 0,093 & 0,000 & 0,000 & 0,000 & 0,620 & 0,000 & \\
\hline SIC stock (Tg) & Pearson Correlation & 0,092 & $-0,537 * *$ & $0,471 * *$ & $-0,582 * *$ & $0,319^{* *}$ & $-0,529 * *$ & 0,043 & $0,991^{* *}$ & 0,043 & $-0,049$ & 0,050 & $1,000 * *$ & 0,051 & 0,050 \\
\hline (Urfa) & Sig. (2-tailed) & 0,361 & 0,000 & 0,000 & 0,000 & 0,001 & 0,000 & 0,673 & 0,000 & 0,672 & 0,630 & 0,621 & 0,000 & 0,618 & 0,620 \\
\hline SIC stock (Tg) & Pearson Correlation & 0,092 & $-0,537 * *$ & $0,471^{* *}$ & $-0,582 * *$ & $0,319^{* *}$ & $-0,529 * *$ & 0,043 & $0,991^{* *}$ & 0,043 & $-0,049$ & 0,050 & $1,000^{* *}$ & 0,051 & 0,050 \\
\hline (Turkey) & Sig. (2-tailed) & 0,361 & 0,000 & 0,000 & 0,000 & 0,001 & 0,000 & 0,672 & 0,000 & 0,672 & 0,629 & 0,621 & 0,000 & 0,617 & 0,620 \\
\hline
\end{tabular}

$\mathrm{p}<0.05^{*}, \mathrm{p}<0.01 * *$ 
In all studies carried out for determining the correlation between carbon soil content of the soils and BD, a very significant negative relationship was specified between carbon and BD. In several studies carried out on this correlation, the statistical significance of the correlation between SOC and BD was determined as $\mathrm{r}^{2}=-0.78, \mathrm{p}<0.01$ ( $\mathrm{Li}$ et al., 2007), $r^{2}=-0.9996, p<0.01$ (Sakin et al., 2011), and $r^{2}=-0.971, p<0.01$ (Sakin et al., 2015).

Revealing a positive relationship between \% clay content of the soils and SOC was positive. This reflected that especially arid and semi-arid region soils were well aerated; SOC could be decomposed in soil under oxidation and long-term insolation (Sakin, 2016). Krull et al. (2013) and Kölbl and Kögel-Knabner (2004) reported that the clay in the soil protected SOC against physical, chemical and biological mechanisms. Clay in the soil protects SOC forming mineral complexes (Burke et al., 1989). There have been some researchers stressing that this powerful relationship between soil clay content and SOC was not global (Percival et al., 2000; Krull et al., 2003). When SOC content of the soils in the Southeastern Anatolia was compared with the SOC contents of the soils in arid and semi-arid areas, is the value was higher in southeastern area. This was reported to be arisen from the rich clay content and limey nature of these soils (Sakin, 2010).

Although clayey nature of the region soil could be considered as a disadvantage at first sight, this was remarkable in terms of protecting SOC against decomposition and disintegration. As known, soil poses difficulties for cultivation and cultivation tools when it contains water over field capacity. When it contains water below field capacity, this could lead to formation of clods during cultivation. In order to eliminate these disadvantages, addition of organic waste to soil would be beneficial.

\section{Conclusion}

SOC contents of the soils in the study area were determined between 0.07 and $1.95 \%$, and lime contents were determined between 12.7 and $42.81 \%$. SOC and SIC concentrations of the soils samples were $0.19-4.44 \mathrm{~kg} \mathrm{C} \mathrm{m}^{-2}$ and $1.53-14.08 \mathrm{~kg} \mathrm{C} \mathrm{m}^{-2}$, respectively. Surface SOC stocks of the soils were calculated between 0.17 and $0.39 \mathrm{Tg}$, and SIC stocks were calculated between 0.033 and $1.25 \mathrm{Tg}$. Surface SIC and SOC ratio of the soils in the study area was 2.29 and within the global average range.

In arid and semi-arid climate regions, soil carbon content is generally low because of the factors such as insufficient precipitation, low biomass and organic carbon intake, high oxidation, use of soil biomass as animal feed, being picked up for burning or as fuel. On the other hand, clayey nature of the soils is significant in terms of SOC content and accumulation. Clay surrounds SOC, and creates organo-mineral complexes, and protects the soil against decomposition and disintegration.

Surface soil, where the most soil organic carbon content (SOC) is found, is important for plant nutrition areas, and activity areas of organisms, and for factors such as soil preservation, and water-holding and infiltration capacity. In this sense, adding organic wastes into the soil could provide positive contributions upon increasing the SOC content of the soils. This application would improve physical, chemical and biological properties of the soil in addition to increasing the nutrients in the soil. 


\section{REFERENCES}

[1] Ak, B.E., Acar, I., Kaska, N. (1998): An Investigation on the Male Determination for Some Female Varieties Throughout Five Years (1992-1996) Grown at Ceylanpinar State Farm in Şanliurfa Conditions. X. GREMPA Seminar, 14-17 October 1996, Meknes (Morocco). - Cahiers Options Mediterraneennes 33: 99-104.

[2] Amundson, R. (2001): The Carbon Budget in Soils. - Annu. Rev. Earth Planet. Sci. 29: 535-562.

[3] Anonymous (1982): Methods of soil analysis. Number 9. Part II. - Madison, Wisconsin. USA.

[4] Arul Pragasan, L. (2016): Assessment of Carbon Stock of Tree Vegetation in the Kolli Hill Forest Located in India. - Applied Ecology and Environmental Research 14(2):169183. doi: http://dx.doi.org/10.15666/aeer/1402_169183

[5] Batjes N.H., Dijkshoorn J.A. (1999): Carbon and nitrogen stocks in the soils of the amazon region. - Geoderma 89 (3-4): 273-286.

[6] Batjes, N.H., Sombroek, W.G. (1997): Possibilities for Carbon Sequestration in Tropical and Subtropical Soils. - Global Change Biol. 3:161 - 173.

[7] Bouwman, R.A., Reeder, J. D., Lober, R.W. (1990): Changes in the Soil Properties in a Central Plains Rangeland Soil after 3, 20 and 60 years of Cultivation. - Soil Science 150: $851-857$.

[8] Bouyoucus, G. J. (1951): A Recalibration of the Hydrometer for Making Mechanical Analysis of Soils. - Agron. Jour. 3: 434 - 438.

[9] Burke, I. C., Yonker, C. M., Parton, W. J., Cole, C. V., Flach, K., Schimel, D. S. (1989): Texture, climate, and cultivation effects on soil organic matter content in U.S. grassland soils. - Soil Sci. Soc. Am. J. 53: 800-805.

[10] Egbe, E. A., Tabot, P.T. (2011): Carbon Sequestration in Eight Woody Non-Timber Forest Species and Their Economic Potentials in Southwestern Cameroon. - Applied Ecology and Environmental Research 9(4): 369-385. doi: http://dx.doi.org/10.15666/aeer/0904_369385

[11] Garcia-Pausas, J., Casals, P., Camareroetal, L. (2007): Soil organic carbon storage in mountain grasslands of the Pyrenees: Effects of climate and topography. Biogeochemistry 82 (3): 279-289.

[12] Houghton, R.A. (2007): Balancing the Global Carbon Budget. - Annual Review of Earth and Planetary Sciences 35: $313-347$.

[13] Israelsen, O.W., Hansen, V.E. (1962): Irrigation Principles and Practices. Third Edition. Capter 8. - John Wiley and Sons, New York.

[14] Jackson, M. L. (1958): Soil Chemical Analysis. Prentige - Hall, Inc., Englewood Cliffs, New Jersey, 498.

[15] Janzen, H. H. (2004): Carbon Cycling in Earth System - a Soil Science Perspective. Agriculture, Ecosystem and Environment 104: 399 - 417.

[16] Janzen., H. H. (1993): Soluble Salts. In Carter, Martin R. (ed.) Soil Sampling and Methods of Analysis. - Lewis Publisher, pp. 161 - 166, USA.

[17] Kölb, A., Kögel-Knabner, I. (2004): Content and composition of free and occluded particulate organic matter in a differently textured arable Cambisol as revealed by solidstate C-13 NMR spectroscopy. - J. Plant Nutr. Soil 167:45-55.

[18] Konen, M. E., Burras, C. L., Sandor, J.A. (2003): Organic Carbon, Texture, and Quantitative Color Measurement Relationships for Cultivated Soils in North Central Iowa. - Soil Sci. Soc. Am. J. 67: 1823-1830.

[19] Krull, E. S., Baldock, J. A., Skjemstad, J. O. (2003): Importance of mechanisms and processes of the stabilisation of soil organic matter for modelling carbon turnover. Functional Plant Biology 30 (2): 207-222.

[20] Lal, R. (1995): The Role of Residue Management in Sustainable Agricultural Systems. Journal of Sustainable Agriculture 5: $71-78$. 
[21] Li, X.G., Li, F.M., Zed, R., Zhan, Z.Y., Singh, B. (2007): Soil physical properties and their relations to organic carbon pools as affected by land use in an alpine pastureland. Geoderma 139: 98-105.

[22] Martinez, M.L., Perez-Maqueo, O., Vazquez, G. (2009): Effects of land use change on biodiversity and ecosystem services in tropical montane cloud forests of Mexico. - Forest Ecology and Management 258 (9): 1856-1863.

[23] Mengel, K., Kirkby, E.A. (1978): Principles of plant nutrition. - International Potash Institute, CH-3048 Worblaufen-Bern, Switzerland.

[24] Milne, E., Paustian, K., Easter, M., Sessay, M., Al-Adamat, R., Batjes, N. H., Bernoux,M., Bhattacharyya, T., Cerri, C. C., Eduardo, C., Cerri, P., Coleman, K., Falloon, P., Feller, C., Gicheru, P., Kamoni, P., Killian, K., Pal, D. K., Powlson, D. S., Williams, D. S And Rawajfih, R. (2007): An Increased Understanding of Soil Organic Carbon Stocks and Changes in Non - Temperate Areas: National and Global Implications. - Agriculture, Ecosystems and Environment 122: 125 - 136.

[25] Munis, M.M., Sakin, E. (2013): Determination of Fertility Status of the Soils of Cizre District. - Tr. J. Nature Sci. 2 (2):38-43.

[26] Novaes Filho, J.P.N., Selva, E.C., Couto, E.G., Lehmann, J., Johnson, M.S., Riha, S.J. (2007): Spatial distribution of soil carbon under primary forest cover in southern Amazonia. - Sociedade de Investigacoes Florestais 31:83-92.

[27] Oladele, O., Braimoh, A. (2014): Potential of Agricultural Land Management Activities for Increased Soil Carbon Sequestration in Africa- A Review. Applied Ecology and Environmental Research 12(3): 741-751. doi: http://dx.doi.org/10.15666/aeer/1203_741751

[28] Paul, E.A., Paustian, K., Elliott, E.T., Cole, C.V. (1997): Soil Organic Matter in Temperate Agroecosystems: Long - term Experiments in North America. - CRC Press, Boca Raton, 424.

[29] Percival, H. J., Parfitt, R. L., Scott, N. A. (2000): Factors controlling soil carbon levels in New Zealand grasslands: is clay content important? - Soil Science Society American Journal, 64 (5): 1623-1630.

[30] Sakin, E. (2010): Carbon stocks and balance of South-eastern Turkey. PhD. Thesis, 234.

[31] Sakin, E. (2013): Carbon balance and stocks in soils of south-eastern region (SAR). Journal of Food, Agriculture \& Environment 11 (3-4): 2186-2189.

[32] Sakin, E., Deliboran, A., Tutar, E. (2011): Bulk density of Harran plain soils in relation to other soil properties. - African Journal of Agricultural Research 6(7): 1750-1757.

[33] Sakin, E., Sakin, E.D., Kizilgöz, İ. (2015): Surface of Carbon Stocks of Mardin District. GAP VII. Agriculture Congress, 28 April-1 May 2015, Sanliurfa, 216-220.

[34] Sakin, E., Sakin, E.D., Seyrek, A. (2014): Amount and Surface of Carbon Stocks of Diyarbakir District. - Journal of Harran Agriculture and Food Science 18 (2): 1-7.

[35] Sakin, E., Seyrek, A., Sakin, E.D. (2015): Comparison of some physico-chemical characteristics and nutrient element status between cultivated and uncultivated soils. Oxid. Commun. 38 (3):1491-1503.

[36] Schlesinger,W.H., Andrews, J.F. (2000): Soil Respiration and the Global Carbon Cycle. Biogeochemistry 48: 7 - 20.

[37] Schwendenmann, L., Pendall, E., Potvin, C. (2007): Surface soil organic carbon pools, mineralization and $\mathrm{CO} 2$ efflux rates under different land-use types in Central Panama. In: Tscharntke T, Leuschner C, Zeller M, Guhardja E, Bidin A (eds) The stability of tropical rainforest margins, linking ecological, economic and social constraints of land use and conservation, Springer Verlag Berlin 2007, 109-131.

[38] U.S. Salinity Laboratory Staff. (1954): Diagnosis and Improvement of Saline and Alkali Soils. USDA Agricultural Handbook, No: 60.

[39] Walkley, A. (1947): A Critical Examination of a rapid Method for Determining Organic Carbon of Soils. - Soil Sci. 63: 251 - 263. 
[40] Xu, X., Liu, W., Kiely, G. (2011): Modeling the change in soil organic carbon of grassland in response to climate change: effects of measured versus modelled carbon pools for initializing the Rothamsted Carbon model. - Agriculture, Ecosystems and Environment 140: 372-381.

[41] Yang, Y., Mohammat, A., Feng, J., Zhou, R., Fang, J. (2007): Storage, patterns and environmental controls of soil organic carbon in China. - Biogeochemistry 84: 131-141.

[42] Yimer, F., Ledin, S., Abdelkadir, A. (2006): Soil organic carbon and total nitrogen stocks as affected by topographic aspect and vegetation in the Bale Mountains, Ethiopia. Geoderma 135: 335-344. 